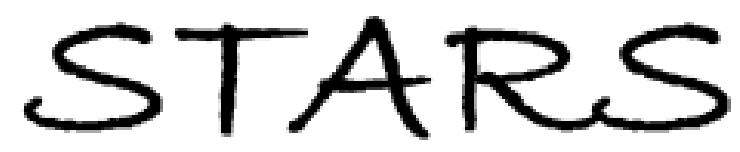

University of Central Florida

STARS

$1-1-2003$

\title{
Transforming education, transforming ourselves: Contributions and lessons learned
}

Karen L. Biraimah

University of Central Florida

Find similar works at: https://stars.library.ucf.edu/facultybib2000 University of Central Florida Libraries http://library.ucf.edu

This Editorial Material is brought to you for free and open access by the Faculty Bibliography at STARS. It has been accepted for inclusion in Faculty Bibliography 2000s by an authorized administrator of STARS. For more information, please contact STARS@ucf.edu.

\section{Recommended Citation}

Biraimah, Karen L., "Transforming education, transforming ourselves: Contributions and lessons learned" (2003). Faculty Bibliography 2000s. 3628.

https://stars.library.ucf.edu/facultybib2000/3628

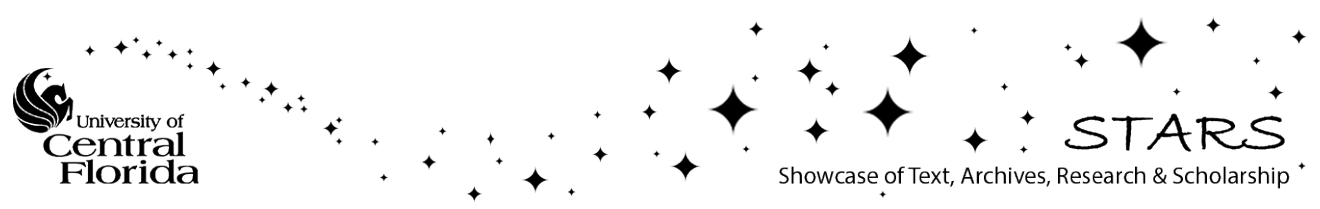




\title{
Presidential Address
}

\section{Transforming Education, Transforming Ourselves: Contributions and Lessons Learned}

\author{
KAREN L. BIRAIMAH
}

Since my student days, two questions have continued to shape my thinking and challenge my mind. As a doctoral student at the State University of New York at Buffalo, Gail Kelly never tired of asking me, "But what is your question?" while Philip Altbach would continually challenge me by saying, "But what does it all mean?" Keeping these queries in mind, I will share with you a two-part question that has continued to perplex me since my days at Buffalo, and bring clarity to its resolution. First, how can the theories and research agendas that abound in comparative and international education be applied to the lived cultures and daily challenges faced by teachers and their students? And then, linking theory to reality, are comparativists obliged to ameliorate these conditions? As I address these questions, I will examine the relationship between researchers, policy makers, and practitioners to determine how they can work together to more effectively achieve the goal of equitable educational opportunities for all students.

As I set about the task of drafting this address, I was well aware of the unique qualities of, and the intellectual challenges posed by, the presidential addresses that had come before mine. Nonetheless, I have chosen to digress somewhat from this more abstract intellectual tradition to deliver a message that focuses on deliberate acts of social transformation within elementary and secondary schools, while simultaneously calling upon comparativists to enrich their academic lives from lessons learned through praxis.

I will begin by focusing on the long-standing debate within the society regarding the intellectual and pragmatic divide between the fields of comparative and international education, and between theorists and researchers on the one hand, and policy makers and practitioners on the other. I will then focus on the serious dilemmas facing public education in the United States and elsewhere, brought about, in part, by conservative political leadership, and how comparative and international educators, in partnership with policy makers and practitioners, can challenge this misguided educational agenda. Throughout this discussion I will explore what comparative and

I would like to acknowledge the helpful suggestions and comments on earlier drafts made by Vandra Masemann, David Post, and Nelly Stromquist.

Comparative Education Review, vol. 47, no. 4.

(c) 2003 by the Comparative and International Education Society. All rights reserved.

0010-4086/2003/4704-0001\$05.00

Comparative Education Review 
international education scholars can do to improve life in schools, and what we can learn from skilled practitioners and effective pedagogical methods.

Moving beyond the False Distinction between Comparative and International Education to Achieve More Effective Educational Transformation

Comparative and international education is replete with notable scholarly works focused on defining and understanding our field, including numerous Comparative and International Education Society (CIES) presidential addresses. My goal in this address is not to provide a detailed summary of these earlier works, but rather to share with you key arguments that have helped to clarify our field while acknowledging schisms that may impede progress toward a more effective and just education for all. Moreover, I follow in the tradition of previous CIES presidents, including David Wilson, Mark Ginsburg, Bob Arnove, Vandra Masemann, Nelly Stromquist, Stephen Heyneman, and others, who have cautioned us against simplistic divisions between theory and practice, researcher and policy makers, and the fields of comparative and international education themselves.

David Wilson reflected upon historical debates within the society that often portrayed the international side of our field as the more descriptive one, concerned with observations of scholars and students traveling to various countries, while the comparative side was portrayed as the more explanatory one, concerned with theory building. ${ }^{1}$ He challenged this notion of two cultures, suggesting that these distinct roles were often blurred. He used the term "academic-practitioner" to define those academics who, for example, might be as firmly ensconced in the university classroom as in a nongovernmental organization (NGO) or bilateral agency. ${ }^{2}$ Rather than argue that comparativists were more likely to produce basic research (knowledgedriven), while internationalists were more likely to do applied research (solution-driven), Wilson suggested that "academic-practitioners are both the center and the periphery engaged in both academic studies of a comparative nature and practical activities in international education." ${ }^{3}$

Robert Arnove built upon this concept of shared identities by highlighting three key dimensions within the field of comparative and international education. First, the theoretical dimension contributed to theory building and analyses of school systems within specific economic, political, cultural, and social orders. ${ }^{4}$ Second, the ameliorative dimension was a means of identifying

\footnotetext{
${ }^{1}$ David N. Wilson, "Comparative and International Education: Fraternal or Siamese Twins: A Preliminary Genealogy of our Twin Fields," Comparative Education Review 38, no. 4 (November 1994): 449-86.

${ }^{2}$ Ibid., p. 456.

${ }^{3}$ Ibid., p. 485.

${ }^{4}$ Robert G. Arnove, "Comparative and International Education Society (CIES) Facing the TwentyFirst Century: Challenges and Contributions," Comparative Education Review 45, no. 4 (November 2001): $477-504$, at 482.
} 
"what can be learned that will contribute to improved policy and practice at home." The third, and to Arnove the most important aspect of comparative education, was the international or global dimension, which was to contribute to international understanding and peace. In Arnove's words, "I believe the international dimension will become an even more important feature of comparative education as processes of globalization increasingly require people to recognize how socioeconomic forces, from what were previously considered distant and remote areas of the world, impinge upon their daily lives. ${ }^{16}$ While some scholars may choose to view comparative and international educators as living in distinct worlds, I believe the key to improving the educational opportunities and outcomes for all children is to strengthen the connections and interdependencies between these two entities.

Developing More Effective Communication between Researchers/Theorists and Policy Makers/Practitioners

As Arnove's approach moves us beyond an unnatural division between comparative and international education, it also builds upon Vandra Masemann's clarion call to value alternative ways of knowing. Masemann has challenged comparativists to rise above the "false dichotomy" between theory and practice and to seek to improve ineffective communications among academics and practitioners. ${ }^{7}$

Mark Ginsberg and Jorge Gorostiaga have also challenged this duplicity of lived cultures, suggesting that the breach between researcher and practitioner is oversimplified and stereotypical. ${ }^{8}$ Their work enriches and extends the previous conversations by focusing on the concept of praxis. For Ginsburg and Gorostiaga, praxis suggests that theoretical arguments have practical, built-in concerns, just as practical interventions usually have theoretical underpinnings. This concept suggests that theorists and practitioners are not two separate groups engaged in distinctive activities but rather two complementary and at times overlapping education entities.

Ginsberg and Gorostiaga's scholarship on the relationship between theorists/researchers and policy makers/practitioners promotes the collective research and praxis model for facilitating effective communication and dialogue between the two camps. ${ }^{9}$ It implores members of both groups to expand their traditionally distinct roles that have focused on the activities of constructing theory or implementing policy. It suggests that both groups be

${ }^{5}$ Ibid., p. 485.

${ }^{6}$ Ibid., p. 488.

${ }^{7}$ Vandra Masemann, "Ways of Knowing: Implications for Comparative Education," Comparative Education Review 34, no. 4 (November 1990): 465-73.

${ }^{8}$ Mark B. Ginsburg and Jorge M. Gorostiaga, "Relationships between Theorists/Researchers and Policy Makers/Practitioners: Rethinking the Two-Cultures Thesis and the Possibility of Dialogue," Comparative Education Review 45, no. 2 (May 2001): 173-96.

${ }^{9}$ Ibid., p. 185. 
viewed as "agents of inquiry and as objects of inquiry," and that both groups are engaged in action and reflection. According to these scholars, not only should "policy makers, administrators, teachers, students, and community members participate in research, but researchers [should] become active participants in various settings, working with others to understand and change schools and society. Members of these various groups [should] engage in dialogue-joint reflection and action - with reference to theory and research as well as policy and practice." ${ }^{10}$ Moreover, discussions on the linkage between theory and practice have not only underscored questions of whether researchers should focus on praxis, but also on whether policy makers and practitioners should read and take research seriously and whether scholarship is capable of making a positive difference in schools.

Based on the premise that comparative researchers are committed to making an impact on the lived cultures of educators and their students, it is necessary that our research first command the attention of policy makers and practitioners. However, given the plethora of unintentional barriers, including the issue of language, it is problematic whether academic research ever gains the full attention of policy makers and, by extension, practitioners in the field. Nelly Stromquist suggests that while "it can be easily observed that numerous changes are in fact occurring in educational policies throughout the world. . . . It is clear that many of these policies are not based on research findings but on values that are disseminated by powerful international agencies or by sheer social contagion." 11

Ginsburg and Gorostiaga extend this concern by focusing on "the limited extent and effectiveness of communication between theorists and researchers, on one side, and policy makers and practitioners on the other." ${ }^{12}$ Moreover, to achieve the greatest effectiveness, there should be free-flowing and multidirectional patterns of communications between these worlds, with shared networks and opportunities for the mutual exchange of ideas and practical objectives. These communications may take place directly in the field, between researcher and practitioner, or they may occur more indirectly through the development and dissemination of written research and theoretical works. What follows are several examples of the challenges and opportunities inherent within communications between researchers and practitioners, whether in the field or on the written page.

Two recent works by comparative and international researchers highlight the dilemmas and challenges faced by researchers when collaborating and communicating with policy makers/practitioners. Laurel Puchner's work on women's literacy in Mali clearly identifies challenges inherent in the development of effective and positive change in the field, arguing that "the com-

\footnotetext{
${ }^{10}$ Ibid., p. 192.

${ }^{11}$ Nelly Stromquist, "Preface," Comparative Education Review 45, no. 2 (May 2001): iii.

${ }^{12}$ Ginsburgh and Gorostiaga, p. 173.
} 
mon conception that researchers have different agendas and different cultural understandings than do practitioners and policy makers can be used to a certain extent to understand the communication problems." ${ }^{13}$ However, Puchner goes on to state that the different-cultures thesis is too simplistic, due to the often overlapping roles of researchers, practitioners, and/or policy makers, and she suggests that substantial role modifications may need to occur in order to promote effective educational change in the field. Joseph Carasco, Nancy Clair, and Lawrence Kanyike extend these thoughts on the promotion of effective dialogue among researchers, policy makers, and the local community when they examine efforts to enhance community participation in programs designed to provide high-quality, equitable education in Uganda. Summarizing their efforts in Uganda, the authors indicate that power, dependence, and the distribution of material resources were major factors challenging increased and effective dialogue among all stakeholders, which they felt was the key to sustained, positive educational change within the community. ${ }^{14}$

Challenges to effective communications not only occur when researchers and policy makers/practitioners collaborate on cross-cultural projects. They also emerge through the transmission of ideas in written research reports and articles. What follows are two practical means for improving the effectiveness of these communications and, by extension, the effectiveness of their application to praxis.

First, we need to write for our intended audience. If theorists and researchers seriously believe their work is of value to policy makers and practitioners, then they may need to consider writing in a less theoretical, abstract, and esoteric style, with vocabulary and syntax that can be followed by educational practitioners in the field. It is not words that make writing great, but the ideas. Yet, if the people you most want to touch with your words cannot understand you, what has been gained? While names will be changed to protect the guilty, we are quite aware of those authors within our own ranks who have great ideas but whose thoughts may be viewed as inaccessible or simply too complicated by those already tired from a challenging day in the field or classroom. Stromquist suggests that while it may be time-consuming and frustrating to write at multiple levels, we can be assured that if we do not, our more conservative colleagues will. A brief glance through less rigorous publications, including Educational Leadership, USA Today Magazine,

\footnotetext{
${ }^{13}$ Laurel Puchner, "Researching Women's Literacy in Mali: A Case Study of Dialogue among Researchers, Practitioners, and Policy Makers," Comparative Education Review 45, no. 2 (May 2001): 242-56.

${ }^{14}$ Joseph Carasco, Nancy Clair, and Lawrence Kanyike, "Enhancing Dialogue among Researchers, Policy Makers, and Community Members in Uganda: Complexities, Possibilities, and Persistent Questions," Comparative Education Review 45, no. 2 (May 2001): 257-79.
} 
the Chronicle of Higher Education, and Phi Delta Kappan, will provide a plethora of conservative articles written to sway opinions and practice. ${ }^{15}$

Second, we need to access mainstream educational publications. As theorists/researchers consider bridging the gap between the two worlds in order to assure more effective implementation of their scholarship, it may be necessary to follow the path less traveled by academe. In particular, because it is important that practitioners share the work of theorists/researchers and critical educators, it may be necessary to publish through more mainstream outlets. Teachers and principals in stressful environments are more likely to read a clearly articulated article published in a familiar trade journal than to tackle late-night reading of the Harvard Educational Review, Educational Theory, or the Comparative Education Review, for that matter. If we want our work and messages to be taken seriously by practitioners, they must first be read. Michael Apple, Peter McLaren, and Mark Ginsburg have set the example by publishing in the Journal of Curriculum and Supervision, the Journal of Teacher Education, and Teaching and Teacher Education. ${ }^{16}$

\section{Moving from Words to Deeds: Beyond Effective Communication to Effective Change}

It is clear that there are vital links between comparative and international educators and between theory and practice. However, we are brought to yet another challenge- the need to move our praxis beyond the relative comfort of policy makers' and administrators' domains in order to improve the lives of classroom teachers and the students they educate. Of course, when we begin to discuss the meaningful application of educational research to ameliorate, emancipate, and empower the learner, we immediately focus on the work of Paulo Freire, whom Joel Spring terms "the most important contemporary philosopher to develop instructional methods designed to end oppression." 17 Though not identified as a comparativist, Freire's theoretical perceptions still frame and inform dialogues regarding the nature and extent of academic involvement in, and responsibility for, making a positive change in the lived cultures of those who inhabit the classroom.

In a review of Freire's work, Michael Apple reiterates these concepts, suggesting that education is not a neutral activity, that it is ultimately con-

\footnotetext{
${ }^{15}$ See, e.g., Diane Ravitch, "A Culture in Common," Educational Leadership 49, no. 4 (December 1991-January 1992): 8-21; Chester E. Finn, Jr., and Diane Ravitch, "Is Educational Reform a Failure?" USA Today Magazine 125, no. 2618 (November 1996): 22-24; Diane Ravitch, "Multiculturalism Yes, Particularism No," Chronicle of Higher Education 37, no. 8 (October 24, 1990): A44; Ron Paige, "An Overview of America's Education Agenda," Phi Delta Kappan (Mav 2002), pp. 708-13.

${ }^{16}$ David J. Flinders and Michael W. Apple, "Forum: What Should Schools Teach?" Journal of Curriclum and Supervision 16, no. 2 (Winter 2001): 112-36; Peter McLaren and Ramin Farahmandpur, "Teaching against Globalization and the New Imperialism," Journal of Teacher Education 52, no. 2 (March-April 2001): 136-50; Mark B. Ginsburg, "Teachers, Economy, and the State: An English Example," Teaching and Teacher Education 4, no. 4 (January 1988): 317-37.

${ }^{17}$ Joel Spring, Wheels in the Head: Educational Philosophies of Authority, Freedom, and Culture from Socrates to Paulo Freire (New York: McGraw-Hill, 1994), p. 153.
} 
nected to multiple relations of domination and subordination, and that it struggles to deconstruct and reconstruct these relations. ${ }^{18}$ Paulo Freire believed that education that was not directly linked to the struggle for emancipation from exploitation was not worthy of the label education. However, Apple cautioned that educational researchers and theorists, including comparative and international educators, must not use the theories and words of Freire simply to gain academic mobility and recognition.

\begin{abstract}
Too many people have employed Freire as writer and person as part of mobility strategies within the social field of the academy. [Pierre] Bourdieu would recognize this as a set of conversion strategies in which members of an upwardly mobile fraction of the new middle class substitute linguistic activity-radical-sounding words and supposed friendship with and closeness to radical actors-for lived political action of a more substantive kind. . . . For some individuals, getting close to Freire, using his books and language, was at least partly a strategy (in Bourdieu's words, a conversion strategy) to career advancement in which being seen as part of his circle gave one legitimacy in the social field of critical education. ${ }^{19}$
\end{abstract}

What gave Freire legitimacy "was not only that he focused on and wrote about a particular kind of education/political praxis, but that he himself had engaged in the hard and disciplined (and sometimes dangerous) work of putting theory and practice together." ${ }^{20}$ Apple cautioned that "some academics may be using Freire's ideas to create an illusion that they are politically committed to social change when they are actually unwilling to make any sacrifices that might endanger their individualistic goals of achieving status and prestige." 21

To stand on the shoulders of Freire, to paraphrase Apple, educators (theorists, researchers, and policy makers alike) must become involved in the daily struggles and social movements that can and are transforming the institutions in which we and others live and work. And unless we sincerely commit ourselves to emancipatory and empowering projects, it is quite clear that the neoliberals, together with the neoconservatives and upwardly mobile factions of the new middle class, will continue to mobilize and infiltrate these institutions with quite a different agenda. For Freire and Apple, the lives and futures of most of our citizens are at stake. They can either become consumers or commodities for sale, or they can become agents of social and cultural transformation. ${ }^{22}$

While Apple, Spring, and Freire would not necessarily identify themselves as comparative or international educators, their messages have affected our field and informed our scholarship. For instance, Philip Altbach and Gail

\footnotetext{
${ }^{18}$ Michael W. Apple, Power, Meaning and Identity: Essays in Critical educational Studies (New York: Peter Lang, 1999), p. 197.

${ }^{19}$ Ibid., p. 200.

${ }^{20}$ Ibid., pp. 200-201.

${ }^{21}$ Ibid., p. 201.

${ }^{22}$ Ibid., p. 217.
} 
Kelly's seminal work, Education and Colonialism, with its focus on classic, internal, and neocolonialism, helped foster critical and transformational debates for nearly 3 decades while other works demonstrate comparative and international educators' continued involvement in issues related to social control and change. ${ }^{23}$

Education, Equity and Transformation, a compilation of selected papers presented at the World Congress of Comparative Education Societies in Cape Town, South Africa, addressed a range of critical issues embedded within comparative and international scholarship. ${ }^{24}$ For example, George Subotzky wrote about the potential role South Africa's historically disadvantaged institutions could play in the reconstruction and development of that country, while Leon Tikly, with lived experiences in South Africa and Tanzania, debated the merits of adopting a postcolonial approach to comparative and international education to ensure "a more holistic and less eurocentric understanding of the relationship between globalisation and education." ${ }^{25}$

Comparative and international scholarship on the Americas also reflected upon key issues of social and educational equity. Emilio Parrado's work challenged the regional inequalities inherent within Argentina's educational system, while David Post's text focused on the effects of child labor, educational policies, the family, and welfare spending on students' educational opportunities in Chile, Peru, and Mexico. ${ }^{26}$ Additional examples of how comparative and international research has focused on social movements can be found in articles describing the role of education in the peace movement in El Salvador and the contesting of Eurocentric curriculum in the schooling of indigenous children in Australia. ${ }^{27}$ Clearly, many comparative and international educators have internalized Freire's challenge to struggle for emancipation from educational exploitation and to become more meaningfully engaged in the improvement of educational opportunities for all children.

\section{Challenging the Power and Politics of the New Right}

Before such transformative education can be effectively infused within the schools, however, comparative and international educators need to address the

${ }^{23}$ Philip G. Altbach and Gail P. Kelly, Education and Colonialism (New York: Longman, 1978).

${ }^{24}$ Crain Soudien and Peter Kallaway, with Mignonne Breier, eds., Education, Equity and Transformation (Dordrecht: Kluwer, 1999).

${ }^{25}$ George Subotzky, "Beyond the Entrepreneurial University: The Potential Role of South Africa's Historically Disadvantaged Institutions in Reconstruction and Development," in Soudien et al., eds., pp. 507-27; Leon Tikly, "Postcolonialism and Comparative Education," in Soudien et al., eds., pp. 603-21.

${ }^{26}$ Emilio A. Parrado, "Expansion of Schooling, Economic Growth, and Regional Inequalities in Argentina," Comparative Education Review 42, no. 3 (August 1998): 338-64; David Post, Children's Work, Schooling, and Welfare in Latin America (Boulder, Colo.: Westview, 2001).

${ }^{27}$ Lillian Moncada-Davidson, "Education and Its Limitations in the Maintenance of Peace in El Salvador," Comparative Education Review 39, no. 1 (February 1995): 54-75; Anne Hickling-Hudson and Roberta Ahlquist, "Contesting the Curriculum in the Schooling of Indigenous Children in Australia and the United States: From Eurocentrism to Culturally Powerful Pedagogies," Comparative Education Review 47, no. 1 (February 2003): 64-89. 
challenges facing practitioners in the era of new Rightist policies. In the twentyfirst century, we need to acknowledge and move beyond a powerful new middle class that is committed, according to Apple, "to the ideology and techniques of accountability, measurement and 'management'." ${ }^{28}$ Researchers and practitioners will also need to deal with the misconceptions and risks involved in the application of free-market theory to education, including vouchers and the form of social theory reflected in academic works such as The Bell Curve. ${ }^{29}$

To initiate a critique of the New Right's approach to educational quality, we might reflect upon carefully articulated research and cross-national studies that have challenged these practices in and beyond the United States. In the discussion that follows, I will draw upon comparative and international research, as well as domestic examples from the United States, to illustrate the complexities of program evaluation, accountability through standardized examinations, marketization of education, and the use of vouchers to promote school choice programs.

Following a business model, many school systems are adopting quantitative, cost/benefit models to evaluate the qualitative results of schooling. In my own state of Florida for example, officials recently announced that they were initiating a new accountability system that would rate every school for "efficiency and effectiveness" by measuring the progress of schools against the cost of achieving it. This policy was reinforced by the U.S. government's plan to add yet another layer of testing and market accountability in all schools through the implementation of President George W. Bush's No Child Left Behind Act. This included the introduction of a new accountability standard of "return on investment," which was designed to show taxpayers which schools "give the most bangs for the buck." 30

Unfortunately, an overreliance on economic accountability approaches is not limited to regional and national systems of education, but also flourishes within a myriad of cross-national projects. Over the years, comparative and international educators have routinely collaborated with donor agencies on cross-national projects that have often employed cost/benefit analysis to evaluate quality. However, in some instances, comparativists have provided us with alternate forms of qualitative assessment that can help move evaluation models beyond formulas of return on investment.

For example, opportunities for comparativists to contribute to the development of more diverse forms of educational assessment have occurred within selected universal primary school projects prompted by the World

\footnotetext{
${ }^{28}$ Michael W. Apple, "Can Critical Pedagogies Interrupt Rightist Policies?” Educational Theory 50, no. 2 (Spring 2000): 229-55, quote on 230.

${ }^{29}$ R. J. Herstein and C. Murray, The Bell Curve: Intelligence and Class Structure in American Life (New York: Simon and Schuster, 1996).

${ }^{30}$ Orlando Sentinel (February 1, 2003), pp. A1, A8.
} 
Conference on Education for All (held in Jomtien, 1990). ${ }^{31}$ In the decade since Jomtien, developing nations, their comparative and international education partners, and donor institutions have strived to develop viable alternative strategies for the delivery and assessment of formal education, though traditional cost/benefit analyses continued to play an overriding role in program assessment. As a case in point, the U.S. Agency for International Development (USAID), the sponsor for both the World Education and the Save the Children models of community-based education in Mali, prepared an assessment document that focused primarily on a comparative cost analysis of these two models. A concluding note in the USAID report reiterates this evaluation practice, stating that "although their long term future is unclear, the USAID-funded community schools demonstrate that there are alternatives to the prevailing public school model of education in Mali (and elsewhere) that are likely to improve student learning and reduce and reallocate costs." ${ }^{2}$

A comparativist associated with the community-based education project in Mali extended this traditional assessment vehicle by introducing alternate methodologies for assessing school quality. For Joshua Muskin, this qualitative assessment "has hopefully revealed the growing value of an evaluation approach that combines conventional systemic indicators of school qualityacademic performance and school efficiency-with measures of local knowledge attainment and use. In the present evaluation, this integrated strategy was instrumental in the process of clarifying the problems and identifying potential resolutions for the many different issues of concern. . . . The adoption of evaluation criteria and strategies that incorporate the nonschool performance and promise of students (and graduates) is clearly critical." 33 These findings certainly strengthen the argument that the New Right's dependence on quantitative/economic assessment measures may limit a true understanding of schooling, equity, and appropriate educational outcomes.

The New Right has also reintroduced the role of a national curriculum and examinations to assure accountability within schools. In the United States, this concern for external supervision and regulation is not only linked to substantial mistrust of producers (in this case classroom teachers), but also to a neoconservative sense of the need to return to a lost past embedded with high academic standards, disciplines, and "real" knowledge. ${ }^{34}$ These drives for a national curriculum, and especially for national testing, are initial

${ }^{31}$ World Conference on Education for All, Final Report of the World Conference on Education for All (New York: UNICEF, World Conference on Education for All, 1990).

${ }^{32}$ Karen Tietjen, "Community Schools in Mali: A Comparative Cost Study," SD Publication Series Technical Paper no. 97 (U.S. Agency for International Development, Bureau for Africa, Washington, D.C., June 1999), p. 88.

${ }^{33}$ Joshua A. Muskin, "Including Local Priorities to Assess School Quality: The Case of Save the Children Community Schools in Mali," Comparative Education Review 43, no. 1 (February 1999): 36-64, quote on 63.

${ }^{34}$ Allan Bloom, Closing of the American Mind (New York: Simon and Schuster, 1988); E. D. Hirsch, Jr., Cultural Literacy: What Every American Needs to Know (New York: Houghton Mifflin, 1987). 
and critical steps on the road to intensified marketization for they provide the necessary data for consumers to perform comparison shopping in the educational marketplace. ${ }^{35}$ Most Americans need look no farther than their state system of public education to find this phenomenon firmly in place.

In Florida, the task of shopping for the best school has just been made infinitely easier thanks to mandated high-stakes testing. Jeb Bush, the governor of Florida and brother of the current U.S. president, has initiated the $\mathrm{A}+$ Plan for Education, which assigns letter grades from A to $\mathrm{F}$ to each public school in Florida based primarily on standardized test scores. Though standardized examinations have long been used in U.S. schools to assess academic achievement and college readiness, this large-scale misuse of high-stakes testing is relatively new.

Comparative and international research, which has routinely examined national high-stakes testing schemes over the years, may help inform educators struggling with new accountability measures while highlighting the uses and abuses of cross-national studies of academic achievement (with data often provided through UNESCO or the World Bank). Noah and Eckstein's comparative analysis of national examination policies in eight countries, for example, suggests that examination systems can either foster educational change or provide a barrier to change. ${ }^{36}$ They posit that while national examinations were once seen as a liberator from unequitable advancement based on privilege and wealth, these exams have also frequently become means to distort educational and career outcomes. Clearly, national examinations may not necessarily provide a fair and equitable means of assessing achievement or identifying students who merit advancement. Todd Fletcher and Darrell Sabers, in a critique of cross-national studies of achievement, extend this argument by cautioning that achievement results can easily be skewed depending on the choice of population sample and content areas. They warn against generalizations when there is no standard curriculum across countries and, most notably, caution educators against promoting a "cognitive Olympics." ${ }^{37}$ Unfortunately, school officials do not always heed this warning. When I open my local paper, I often find articles and statistical tables that liken standardized test results to sporting events, rather than to limited measures of school quality.

This determination by the New Right to misuse high-stakes standardized examinations as a tool for accountability has led (conveniently) to a greater use of free-market theories, including the use of choice plans and vouchers by students escaping "failing" schools. School improvement literature, often

\footnotetext{
${ }^{35}$ Apple, "Can Critical Pedagogies," p. 238.

${ }^{36}$ Harold J. Noah and Max A. Eckstein, "The Two Faces of Examinations," in Doing Comparative Education: Three Decades of Collaboration, ed. Harold J. Noah and Max A. Eckstein (Hong Kong: University of Hong Kong, 1998), pp. 211-29.

${ }^{37}$ Todd V. Fletcher and Darrell L. Sabers, "Interaction Effects in Cross-National Studies of Achievement," Comparative Education Review 39, no. 4 (November 1995): 455-68, at 466.
} 
driven by conservatives, has not only focused on quantitative schemes for measurement and assessment but on the marketization of education as well. In his detailed critique of educational markets and educational performance, Apple makes a clarion call to educational theorists and researchers to challenge free-market theories, wherein proponents of "choice" have assumed that competition between schools will improve efficiency while providing new opportunities for disadvantaged students. However, for the poor, these new opportunities remain generally unrealized. In Apple's opinion, voucher programs often help to reproduce inequalities based on race or class while doing little to ameliorate social and cultural inequalities. ${ }^{38}$

In Florida, students who attend schools that receive two F's in 4 years, based primarily on standardized test scores, are qualified to receive state vouchers to attend any state or private/parochial school. However, like most voucher plans, the poor do not have the necessary financial resources to make these vouchers viable. As many private schools have tuitions that far exceed the face value of these vouchers, and require parents to own their own car (in addition to having schedules that allow for car pools), this plan does very little to provide real choice for the poor.

Arguments supporting choice, and the results of various voucher programs, have also been dealt with from a comparative perspective with similar conclusions. Martin Carnoy's work on the national voucher systems in Chile and Sweden, for example, analyzed the arguments made by proponents that voucher programs were cost effective, led to no reduction in program quality, and were a means to improve education during periods of severe economic constraints. ${ }^{39}$ Similar to critiques of U.S.-based voucher programs, Carnoy's comparative study of voucher programs in Chile and Sweden concludes that "there is no persuasive evidence from these or other voucher plans that private schooling is more effective than public, and there is mixed evidence on whether private schools are more cost-effective. Not every income group benefits from increased choice. Less educated, lower-income parents have less physical access to private alternatives because private schools tend to locate in larger cities. Better educated parents also tend to move their children out of schools with significant enrollment of lower-income, lower academically performing pupils when choice exists." ${ }^{40}$

Clearly, the challenges from the New Right are real and pervasive. These challenges require the collaboration of comparativists and international educators, as well as researchers and practitioners, to analyze and benefit from internal and cross-national critiques of school accountability plans. The call

\footnotetext{
${ }^{38}$ Apple, "Can Critical Pedagogies" (n. 28 above), p. 232.

${ }^{39}$ Martin Carnoy, "National Voucher Plans in Chile and Sweden: Did Privatization Reforms Make for Better Education?" Comparative Education Review 42, no. 3 (August 1998): 309-37.

${ }^{40}$ Ibid., p. 335.
} 
to make our research applicable, and to make our research count, has never been more evident.

Transformational and Reconstruction Theory Applied in the Classroom

As a student at the State University of New York at Buffalo, I often attended doctoral seminars after a long day of teaching and negotiating the challenges of an inner city high school. My days were filled with weapon searches, struggles to find duplicating paper, writing on warped blackboards listing dangerously to the starboard, harrowing trips to the restroom in predawn darkness (the electricity had been shut off as a safety precaution due to ceiling leaks), and midmorning trips to the back door to sneak in a perpetually tardy student who had been forced by alcoholic parents to work late nights to support the family. My seminars were often facilitated by some of the leaders in our field, including Gail Kelly, Philip Altbach, and Lois Weis. They provided me with many timely paradigms to theorize and rationalize the inequities and heartbreaking situations I lived with in an urban school every day, but they did nothing to ameliorate my students' daily battles to survive and prosper. Theories explaining the reproduction of societal inequalities helped me to understand my students' lived cultures, but gave me no real guidance to reconstruct this reality.

The frustration I felt as a teacher and student at Buffalo has carried over into my career in academe. I remember being assigned, as a new assistant professor, to supervise mathematics interns at a secondary school located in an upscale suburb of Orlando, Florida. I can still recall the feelings of awe and anger that welled up in me as I gazed at a fully equipped, modern room with comfortable desks, state-of-the-art equipment, and a fully certified math teacher-the kind of opportunities rarely available to my students in the decaying inner city schools.

My experiences in the field, as well as yours, have introduced real faces and lived cultures into the continuing debate over a meaningful impact of theory on praxis. They have also given meaning to the Freirian charge to engage in the emancipation of all students from the often squalid and unequitable realities of life in the educational trenches.

During the mid 1990s, a CIES presidential debate, of sorts, emerged between Steven Heyneman and David Wilson regarding the viable outcomes of our field. In his 1993 presidential address, Heyneman argued that "comparative education is alive and well at the periphery but that it is dead in the center where attention is devoted to academic issues with no obvious products." ${ }^{\prime 1}$ David Wilson countered this argument in his own 1994 presidential address. Wilson felt that Heyneman had ignored the society's development

\footnotetext{
${ }^{41}$ Stephen P. Heyneman, "Quantity, Quality and Source," Comparative Education Review 37, no. 5 (November 1993): 372-89, quote on 386.
} 
of "a new breed of individual, the academic-practitioner, who has been equipped with a viable academic understanding of comparative education and who has used that orientation to further the meliorative function common to both international and comparative education in his or her subsequent international activities." ${ }^{42}$ For Wilson, hybrid academic-practitioners oftentimes came out of the trenches, for example, through the U.S. Peace Corps, the Canadian University Service Overseas, the British VSO, the German and Dutch voluntary services, or elementary and secondary teaching, to become comparativists who strove to merge their academic training with meaningful applications in the field.

This concept of a vibrant academic-practitioner also has its counterpart, the practitioner-researcher. Michael Crossley vigorously supports the case for embracing practitioner research that is firmly grounded in case studies of professional practice. ${ }^{43}$ Basing his argument on Peter Jarvis's work The Practitioner Researcher, Crossley challenges the traditional and inflexible relationship between theory and practice, stating that researchers can no longer afford to be distanced from practice and practitioners and that the valuable work of practitioner-researchers has helped to dissolve this unnatural separation. ${ }^{44}$ Indeed, the practitioner-researcher has become an irreplaceable part of the learning community, modeling how the challenges and changing needs of students can be met through a firm knowledge of praxis. For Jarvis, "their research illustrates that in the learning society, many . . . research projects need to be small, local, and practical, producing both a personal theory and information about practice." 45

Expanding this line of reasoning, we must also consider the possibility that positive educational change comes not only from academics or practitioners, but also from students. Multicultural education literature abounds with examples of students as the newest form of practitioner-researcher. Like Christine Sleeter and Carl Grant, James Banks affirms the Freirian concept that meaningful programs in multicultural education are focused on developing students who not only have a global perspective, but also have a sense of efficacy through critical reflection that ultimately leads to action to transform or reconstruct the world. ${ }^{46}$

This perspective has the potential to move our field beyond perennial debates over dichotomies and linkages to a position that values the inclusion

${ }^{42}$ Wilson (n. 1 above), p. 450.

${ }^{43}$ Michael Crossley, "Bridging Cultures and Traditions in the Reconceptualisation of Comparative and International Education," Comparative Education 36, no. 3 (August 2000): 319-32.

${ }^{44}$ Peter Jarvis, The Practitioner Researcher (San Francisco: Jossey-Bass, 1999).

${ }^{45}$ Ibid., pp. 166-67.

${ }^{46}$ Christine E. Sleeter and Carl A. Grant, Making Choices for Multicultural Education: Five Approaches to Race, Class, and Gender, 4th ed. (New York: Wiley, 2003); James Banks, ed., Multicultural Education, Transformative Knowledge, and Action: Historical and Contemporary Perspectives (New York: Teachers College Press, 1996) 
of our research objects. Through these new parameters, theorists and researchers may consider "toiling in the vineyards" as a means for their work to effect positive change in the classroom while practitioners, both teachers and students, become researchers who can inform and enrich theory.

Many of us have tried, with various degrees of success, to become Wilson's hybrid academic-practitioner. Although I need not belabor this point, I will share with you a few examples of how this approach can potentially inform academe and, in so doing, can transform the lived cultures of the students it touches.

While the call for transformational educators and curriculum that promotes social reconstruction is not new, only now is it becoming more commonplace within educational dialogues. The literature is now beginning to reflect this perspective as we hear of teachers becoming transformational educators. In a text aimed at graduate education students, Joan Strouse suggests that teachers should "not only strive to be responsive to their students but work as well for social justice beyond their classrooms. In many ways, such teachers model for their students, and for us academics, through their activism, their visions of what responsible adulthood and citizenship might mean. . . . They are able to engage their students in a transformative dialogue-one that empowers students to view and experience their worlds in new ways and to understand that it is within the students' capability to act on their world and to change it." ${ }^{47}$

Sleeter and Grant maintain that students, particularly those who are members of oppressed groups, need to understand the nature of oppression and how their ascribed characteristics, such as race, class, and gender as well as their culture, are factors in that oppression. Ideally, this understanding should empower students to articulate their own goals and their own visions of social justice for all groups and to work constructively to achieve these goals. Transformational education, which may also be identified as critical teaching or multicultural education, is underscored in Sleeter and Grant's drive to develop education that is socially reconstructionist and reflects Freire's view that people should learn to question and to become empowered to envision, define, and work toward a more humane society.

In three brief examples that follow, I will illustrate how teachers can infuse comparative, critical, and multicultural perspectives within their classrooms, and how these same practitioners, and their students, can inform academe through their own field research and experiences. The first example is of an American secondary teacher in Portland, Oregon, whose classroom pedagogy suggests a Freirian or reconstructionist approach. William Bigelow states that "as a teacher I want to be an agent of transformation, with my classroom as a center of equality and democracy — an ongoing, if small, cri-

\footnotetext{
${ }^{47}$ Joan H. Strouse, ed., Exploring Socio-Cultural Themes in Education: Readings in Social Foundations, 2d ed. (Columbus, Ohio: Merrill Prentice-Hall, 2001), pp. 291-92. 
tique of the repressive social relations of the larger society. . . . I hope my classroom can become part of a protracted argument for the viability of a critical and participatory democracy." 48 This perspective certainly sets Bigelow apart from what he perceives as a primary function of education in the United States: "to reproduce a class society, where the benefits and sufferings are shared incredibly unequally." 49 This perspective situates Bigelow's educational philosophy near many theorists and researchers who have written about oppression, empowerment, and the like. I say near, because unlike most of these scholars, he lives out this philosophy in the classroom.

Bigelow infuses emancipatory pedagogy into his social studies classes by using historical concepts as launch platforms to explore themes in his students' lives, while using students' lived experiences to explore history and contemporary society. As an example, through role-play, Bigelow had his students portray the Cherokee Indian removal to discover the forces that pushed the Cherokee west of the Mississippi River against their will. Then, Mr. Bigelow asked his students to write about a time when their own rights were violated, recapturing how they felt and what they did, if anything, about this injustice. Throughout the lesson, Bigelow's goal was for the students to find social meaning in individual experience, and to validate their own lives as important sources of information and learning. Bigelow's objective was for his students to internalize the notion that they could create knowledge, not simply absorb it from the dominant culture.

While this is a splendid example of Freirian pedagogy, what is significant to our understanding and enrichment of the concepts of hybrid academicpractitioner and teacher-researcher is Bigelow's use of students as researchers. For Bigelow, this was a natural outgrowth of his determination to infuse emancipatory pedagogy within his classes. He explains, "In my experience as a teacher, whether students write about inequality, resistance, or collective work, school is the most prominent setting. Therefore, in our effort to have the curriculum respond to students' real concerns, we enlist them as social researchers, investigating their own school lives. . . . We assign them to observe their classes-as if attending for the first time. We ask them to notice the design of the classroom, the teaching methodology, the class content ... the grading procedures ... [and whether] the teacher promote(s) questioning and critique or obedience and conformity."

Unfortunately, through this process of investigation, Bigelow found that his students also came to see themselves as powerless cogs in a machine that reproduced the inequities of the larger society. This realization caused Big293

${ }^{48}$ William Bigelow, "Inside the Classroom: Social Vision and Critical Pedagogy," in Strouse, ed., p.

${ }^{49}$ Ibid., p. 293.

${ }^{50}$ Ibid., p. 296. 
elow to adjust his curriculum to provide students with a pedagogical model akin to Sleeter and Grant's social reconstructionism.

In his conclusion, Bigelow makes a plea to all teacher educators to model this type of participatory and emancipatory pedagogy in their own university classrooms, with the hope that our preservice teachers will become exemplary future models of transformational pedagogy. We might also learn from this example that educators such as Bigelow have the potential to inform our research and bring validity to our theories. We should therefore embrace these practitioners as vital links to the classrooms we purport to transform.

My second example, that of a teacher in-service program in Brazil, suggests that closer partnerships between academics and teacher-researchers can be beneficial for all involved. Researchers and theorists can infuse their agendas with a strong dose of reality, while the teachers' lived cultures can achieve a deeper meaning when viewed through theoretical lenses. Exemplifying this partnership is the work of Ruth Pereira, whose in-service education grew out of a university program designed to provide for the professional development of Rio de Janeiro's schoolteachers through action research. This approach not only provided rich linkages between practitioner and academic professional lives, but also allowed participants to reflect upon their own process of investigation in the context of where it occurred. It also facilitated, in the words of Pereira, an "analysis of the relationship between the act of researching and pedagogic practice." ${ }^{1}$

This project, based in the elementary schools of Rio de Janeiro, involved primary teachers, university undergraduates, and university faculty. It engaged these educators in a shared learning experience that included discussing, analyzing, and interpreting the data collected by teachers in their own classrooms. Through a process of interpreting classroom research records, teachers were able to see the relation between theory and their daily practice, by observing how changes in their pedagogical approaches directly affected the quality of their students' learning. In these instances, we see the academic community working together to facilitate more emancipatory and effective pedagogy in the classroom. For Pereira, an emancipating pedagogy "must be questioned and evaluated by teachers and students in their own practice, considering the teaching and learning process as a theme, and discussing procedures in order to develop a praxis committed to change. . . . One of the strategies to achieve this aim is the reconstruction of pedagogical ground by action research, whereby the theory-practice dialectic is manifested in the constant facing of conflicts which collectively but slowly inform theory and are explained by it." ${ }^{22}$

\footnotetext{
${ }^{51}$ Ruth Da Cunha Pereira, “Teachers' In-Service Education: A Proposal for Turning Teachers into Teacher-Researchers," in Tradition, Modernity and Post-Modernity in Comparative Education, ed. Vandra Masemann and Anthony Welch (Boston: Kluwer, 1997), p. 570.

${ }^{52}$ Ibid., p. 573. 
As the final example, Gustavo Fischman's analysis of the professional preparation of elementary school teachers in Argentina makes valuable contributions to the fields of comparatiave education and to effective teacher preparation. ${ }^{53}$ Because Fischman based his research on elementary education teachers in training and the faculty members who prepared them, the work goes to the core of the educational process. He has also contributed to comparative education and teacher training research methodology by infusing portraiture research and insisting on the importance of context.

In the cases sited above, we see how teachers and researchers enrich their professional lives by linking theory and practice, and teachers who exemplify how theoretical research can ameliorate and enrich the lives of students. However, from a comparative perspective, it should be noted that the contextual framework for each of these works affected the application of theory to praxis. As Bigelow lived in a context very different from either Pereira's or Fischman's, his effort was more of an individual one, whereas the Brazilian and Argentine examples, within a more leftist political context, afforded greater teacher collaboration.

\section{Political and Social Activism: Moving to the Revolutionary Margins}

To this point, I have shared with you concerns about blending our academic foci in order to advance and enrich our fields. I have also discussed our shared responsibilities, not only to bridge these gaps, but to ensure that our work truly makes a difference in the classroom. However, in making these arguments, I have focused exclusively on what I consider to be the more moderate side of transformational and critical education paradigms, and I have not focused on the more revolutionary perspectives and practices, including the academic as activist. In the last portion of this address, I would like to examine the role of the academic as political and social activist.

To begin, I would like to examine some observations on professors and activism developed by Philip Altbach. ${ }^{54}$ For Altbach, faculty activism has generally been more indirect than student activism, which has occasionally toppled governments. Activism by faculty is generally confined to professional writings and speeches, and professors are less likely to engage in social or political reconstruction. In Altbach's words, "Most professors, even in relation to controversial matters of public policy, see themselves as experts, providing information and research-based analysis rather than directly participating in political disputations. ${ }^{" 55}$

However, while overt political activism is rare, there are clear instances

\footnotetext{
${ }^{53}$ Gustavo E. Fischman, Imagining Teachers: Rethinking Gender Dynamics in Teacher Education (New York: Rowman \& Littlefield, 2000).

${ }^{54}$ Philip Altbach, Comparative Higher Education: Knowledge, the University and Development (Hong Kong: University of Hong Kong, 1998).

${ }^{55}$ Ibid., p. 136.
} 
when it has occurred. According to Altbach, we are more likely to find politicized faculty members in developing countries than in industrialized nations. The level of activism also varies with the times. For example, in most countries, the academic atmosphere was far more politically charged in the 1960s than in the 1990s. Moreover, in Altbach's words, "while an important minority of professors sees itself as an oppositional intelligentsia, most faculty, even during periods of activism, are politically uninvolved. It is quite unusual, although by no means unprecedented, for professors to become active in radical or revolutionary politics. . . . In a few instances, professors have been involved in revolutionary movements in the Third World. . . . More often, professors have been involved in more moderate movements for civil liberties and political change. ${ }^{56}$ For Altbach,

\footnotetext{
Academic activists who are critics of established social or political institutions or policies are more controversial than those who provide expertise or who are involved in campus-based politics. They are mostly cosmopolitans who have access to the media and have a claim to expertise in their fields. They may be senior scholars at key universities. They have the self-confidence to speak out on issues and the security of tenure and reputation. . . . Critical scholars are often more ideologicallyoriented than their peers and have a broader political perspective on society and government. Traditionally, [these] professors have been to the left of the political spectrum in their societies. ${ }^{57}$
}

When one applies Altbach's conception of critical scholarship to the fields of comparative and international education, the writings of Gail Kelly and Birgit Brock-Utne emerge, as well as the more general works of Peter McLaren and Henry Giroux. ${ }^{58}$ For example, Gail Kelly was critical of the terms "women's liberation" and "women in development" for she saw them as another means of blaming women for their lack of success in the public arena. Kelly felt that it was inadequate to simply concentrate on providing opportunities for women, and that it was critical to analyze their situation within a broader framework and to understand that the denial of full equality to women could serve specific political ends. ${ }^{59}$

More recently, this tradition of critical comparativists has continued with the work of Brock-Utne, who has challenged the agendas of the World Bank and other major donors by asserting that their policies have led to the intellectual recolonization of the African mind. Based on a dependency theory of international development, Brock-Utne contends that educational schemes

${ }^{56}$ Ibid., pp. 138-39.

${ }^{57}$ Ibid., p. 142.

${ }^{58}$ David H. Kelly, ed., International Feminist Perspectives on Educational Reform: The Work of Gail Paradise Kelly (New York: Garland, 1996); Birgit Brock-Utne, Whose Education for All? The Recolonization of the African Mind (New York: Falmer, 2000); McLaren and Farahmandpur (n. 16 above), pp. 136-50; Henry A. Giroux, Border Crossing (New York: Routledge, 1992).

${ }^{59}$ Kelly, ed. 
in poor countries remain highly dependent on donors from the north and calls for a Julius Nyerere form of education for self-reliance. ${ }^{60}$

Though not necessarily comparativists, the works of McLaren and Giroux have also informed and enriched our critical research agendas. For example, in his work on revolutionary pedagogy, McLaren suggests that the aim of his writing is to develop a critical consciousness among both students and teachers in order to build working-class solidarity and opposition to global capitalism. ${ }^{61}$ Moreover, noting the growth of transnational corporations' sponsorship of university research centers, McLaren warns us that these corporate donations have resulted in the "high-tech colonization of education, and . . . recent attempts by corporations to influence policy and curriculum decisions in urban schools." 62

While McLaren's work has often been encased in a neo-Marxist vocabulary that has focused on revolutionary working-class solidarity, the transformation of capitalist social relations of production, and the like, it has also embraced more moderate theorists who have viewed education as a means to ameliorate the lives of students. For example, McLaren promotes "a revolutionary working-class pedagogy [that] stresses the importance of acquiring a critical literacy-where literacy is defined as a practice of reflecting, analyzing, and making critical judgments in relation to social, economic, and political issues. . . . Furthermore, it invites subordinate groups to represent through classroom interaction and dialogue their lived reality in relation to objective social structures that shape their lives." ${ }^{3}$

This philosophy seems closely linked to that of the secondary social studies teacher who employed a transformational pedagogy to empower his students. It certainly reflects the theories of Spring and Freire, though practitioners (and even some comparative and international educators) might have found these latter examples easier to follow than McLaren's earlier works.

\section{Summary and Conclusions}

This address has argued that the distinctions between comparative and international education, as well as those between researchers/theorists and policy makers/practitioners, are often blurred, though not negated. I have also suggested that the key to improving educational opportunities and outcomes for all children may be to focus on the strength of the connections and interdependencies between these differing entities. To this end, I have argued for more effective two-way communications between theorists/researchers and policy makers/practitioners so that each entity's unique con-

${ }^{60}$ Brock-Utne.

${ }^{61}$ McLaren and Farahmandpur (n. 16 above), p. 136.

${ }^{62}$ Ibid., p. 141.

${ }^{63}$ Ibid., p. 144. 
tributions can be recognized and integrated into projects designed to ameliorate the lived cultures and daily challenges faced by teachers and their students.

Throughout this address, I have provided numerous examples to demonstrate how comparative and international education scholarship and methodologies have remained central to debates regarding the contestation of oppression and neocolonialism, measurement and evaluation of schooling, vouchers, and the effects of the New Right on marginalized students. Moreover, I have provided examples of how teachers can infuse comparative, critical, and multicultural perspectives within their classrooms, and how these same practitioners and their students can inform academe through their own action research and experiences. Finally, I have demonstrated how critical scholarship has become a part of comparative and international education scholarship, and how those critiques have helped to focus attention on educational dilemmas neither limited by nor defined by national boundaries.

Clearly, comparative and international education is brimming with contesting paradigms, linkages, and dichotomies, some of them false, some not. As we reflect upon our field's history, we can see it as an incubator for the development of a powerful praxis that is capable of transforming schools and students' lives. The fields of comparative and international education have grown in significance, but need to remain connected with their roots: the schools, the teachers, and the everyday challenges of delivering a pedagogically sound and socially relevant curriculum where it counts, in the world's classrooms. 